\title{
Aphyllophoroid fungi of the Naryshkinskij Natural Park, Orel Region, Russia
}

\author{
Sergey V. Volobuev \\ Laboratory of Systematics and Geography of Fungi, Komarov Botanical Institute, Russian Academy of Sciences, \\ Professor Popov str., 2, St. Petersburg, 197376, Russia. \\ E-mail: sergvolobuev@mail.ru
}

\begin{abstract}
The first data on aphyllophoroid Basidiomycetes of the Naryshkinskij Natural Park (Orel Region, European Russia) are presented. The annotated list of 92 species in 60-70-year-old secondary forest ecosystems is provided, including four new species (Hericium cirrhatum, Hydnum repandum, Odonticium septocystidia, Polyporus tubaeformis) for the Orel Region. The polypore species Antrodia hyalina recently discovered from Russia also has been found on the studied territory, from deciduous forest communities where Populus tremula is presented as a subdominant tree. Data on substrate and habitat type are listed for each species, and the numbers of herbarium specimens (LE, OHHI) are cited. The predominance of aspen and birch wood associated fungi is shown. Some rare and threatened in Europe species such as Antrodiella fragrans, Hericium cirrhatum, Perenniporia narymica, Punctularia strigosozonata, and Skeletocutis odora are recorded and discussed.
\end{abstract}

\section{INTRODUCTION}

Aphyllophoroid fungi are an essential part of terrestrial ecosystems providing the process of wood destruction, soil formation, and matter and energy cycling. Currently this group of Basidiomycetes is taxonomically integrated and it combines fungi with different life strategies (wood and litter decomposers, mycorrhizal and parasitic species), having basidiomata with a non-gilled hymenophore (Hansen \& Knudsen, 1997; Kotiranta et al., 2009). The present work deals with different life forms of aphyllophoroid fungi, including polypores, corticioids, clavarioids and hydnoids.

The Orel Region situated in the Centre of European Russia (Fig. 1) as well as many other Russian areas was poorly investigated until recently. This region has a long history of economic development of the land, including deforestation and urbanization. The territory was initially covered with the broad-leaved forest vegetation type (with the predominance of Quercus robur, Tilia cordata, Fraxinus excelsior, Acer platanoides) and before the beginning of the 19th century deciduous forests occupied more than half of the Orel Region (Ogureeva et al., 2006), but to date forest fragments (up to $8 \%$ of the whole area) have remained only in protected habitats. The present article is a continuation of previous studies (Kotkova et al., 2011; Volobuev, 2011, 2012, 2013; Volobuev \& Bondartseva, 2012) devoted to the investigation of species diversity and ecological peculiarities of aphyllophoroid fungi in the Orel Region and focuses on forest ecosystems of the Naryshkinskij Natural Park as one of regional protected areas.

The Naryshkinskij Natural Park was established in 2001 and is located $40 \mathrm{~km}$ westwards from the Orel city between the Orlitsa and the Tson rivers $\left(52^{\circ} 56-57^{\prime} \mathrm{N}, 3^{\circ} 39-42^{\prime} \mathrm{E}\right)$. This territory covers a square of $51.2 \mathrm{~km}^{2}$ and lies in the central part of the Central Russian Upland. The Naryshkinskij Natural Park has a moderate continental climate with mostly western winds and the average annual precipitation quantity equal to $550-600 \mathrm{~mm}$. The average monthly temperatures change from $-8.5^{\circ} \mathrm{C}$ in January to $18.2^{\circ} \mathrm{C}$ in July. The most widespread soil types in the area are grey and dark-grey forest soils (Sharapenko, 2000).

Natural vegetation was considerably transformed here during the Second World War when the oak-dominated forests were completely cut down. To date most of the park area (ca 75-80\%) is occupied by birch and aspen second-growth forests which have been formed as a result of recovering succession during 60-70 years after disturbance. Pine and oak trees occur as 50-60-year-old cultural plantations covering no more than one third of the forest area. According to the present-day flora investigation 


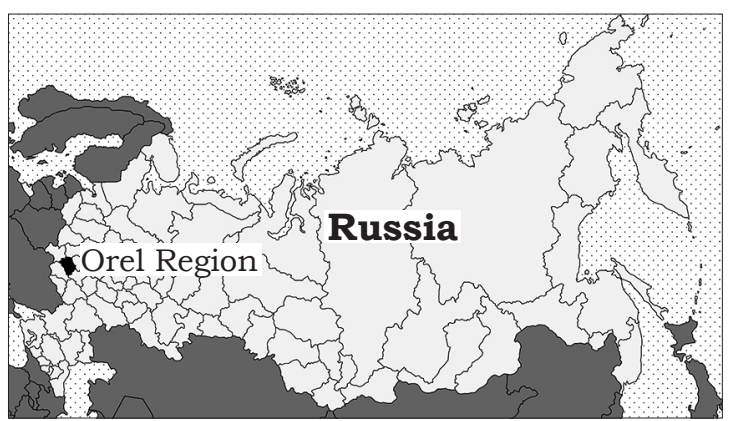

Fig. 1. The location of the Orel Region, Russia.

(Kiseleva et al., 2010) about 500 vascular plant species grow on the Naryshkinskij Natural Park, including 8 species protected by the Red Book of the Orel Region.

Studies of aphyllophoroid fungi have never been carried out on the present territory. For this reason the aim of this work was to inventory the species diversity of these Basidiomycetes and to reveal their substrate preferences.

\section{MATERIAL AND METHODS}

The specimens of aphyllophoroid fungi were collected by the author in June and October 2011, and October 2012 with conventional methods for mycological field work in all the forest types of the park. Forest types were classified according to principles of the dominant classification of vegetation (Gribova et al., 1980). Two main groups formed by aspen and birch forests were divided into different types depending on the presence of subdominants and grass cover composition. Six types were distinguished among the birch forests: aspen-birch forest, aspen-oak-birch forest, oak-birch forest, oakaspen-birch forest, cereal-grassy birch forest and oak-birch with Pteridium aquilinum forest. The aspen forests were presented by four types: grassy aspen forest, birch-aspen forest, birchaspen forest associated with Pteridium aquilinum and oak-birch-aspen forest. In addition, mixed forests have been divided into two groups, viz., oak-pine-birch forests and pine-birch forests.

For the species identification basidiomata samples were examined with the light microscopy technique and the standard set of chemicals (KOH, Melzer's reagent, Cotton Blue) (Kirk et al., 2008).
The annotated list of aphyllophoroid fungi is given in alphabetical order. Names of taxa are presented according to the Index Fungorum (29 March 2013). Each species is accompanied by Latin name, data on substrate, plant community (forest type), and references to the specimens deposited to the herbaria of Komarov Botanical Institute, St. Petersburg (LE) and Orel State University, Orel (OHHI). New species to the Orel Region are marked with an asterisk.

\section{RESULTS AND DISCUSSION}

All of 92 aphyllophoroid fungi species from 56 genera were registered for the first time for the studied territory. The most abundant genera are Hyphodontia and Trametes presented by seven and six wood-inhabiting species, respectively. Four species, Hericium cirrhatum, Hydnum repandum, Odonticium septocystidia and Polyporus tubaeformis, are new to the Orel Region. Hydnum repandum is a hydnaceous stipitate mycorrhiza-forming species and broadly distributed in deciduous and coniferous forests of Europe, Asia, Australia and North America (Breitenbach \& Kränzlin, 1986). Two species Hericium cirrhatum and Polyporus tubaeformis - were found on dead wood (lying trunks) of Populus tremula in the Naryshkinskij Natural Park. The former fungus has an inconspicuous nature and may not develop fruit bodies every year. Similarly to other Hericium taxa, it prefers mature deciduous forests, where wood on required stage of decay exists, and therefore the park environments could be favorable for fungal growth. Occasionally Hericium species can be found in young woodlands, artificial plantations or disturbed forest ecosystems, and it seems to be an adaptation to fruiting and spore scattering under conditions of competitor species absence.

Polyporus tubaeformis is a boreal fungus, rather common in the northern part of the Fennoscandinavian peninsula (Núñez \& Ryvarden, 1995), where it grows on dead wood of Alnus, Betula, Salix, and more rarely on Populus and other trees. Based on known distribution of Polyporus tubaeformis in northern California and the mountains of North Carolina, Krüger et al. (2006) considered the species extant across the Canadian boreal forest belt, as well as across the Siberian counterpart. We supposed that this species might be found in the northern parts of the Orel Region, particularly in the "Orlovskoe 
Poles'e" National Park, which includes a few southern boreal forest communities along with mixed and broad-leaved ones. Apparently the preference of aspen among other phorophytes (alder, birch, willow, etc.) as substrate is determined by the high competition of $P$. tubaeformis with lignicolous Basidiomycetes occuping different deciduous trees and having an ecological optimum under conditions of the Orel Region, viz., nemoral zone.

Odonticium septocystidia occurs on decayed deciduous wood in several European countries and the Caucasus, but overall very rarely (Eriksson et al., 1978; Bernicchia \& Gorjón, 2010). It was registered on fallen logs of Quercus robur in the park, but still there are deficient data for detailed characteristic of its ecological peculiarities.

The polypore species Antrodia hyalina recently discovered from Russia also has been found on the studied territory. According to the author description (Spirin et al., 2013), most of collections of $A$. hyalina were made in old-growth mixed or broad-leaved forests with abundant Populus tremula, and in the Orel Region this fungal species has been known from deciduous forest communities where aspen is present as a subdominant tree.

The substrate type analysis has shown that the most preferred tree species for aphyllophoroid Basidiomycetes was Populus tremula, on which 44 fungal species were observed. The second woody substrate according to the number of inhabiting species is Betula pendula that has 32 species of aphyllophoroid fungi as consorts. Oak trees in the explored region are edificators for zonal type of forest communities. Quercus robur is the substrate for only 20 fungal species, that is likely to be due to the immaturity of the forest ecosystems and the insufficient quantity of oak woody debris with necessary sizes and decay stage. Less than five species of aphyllophoroid Basidiomycetes were found on other substrate types such as coarse and fine woody debris of Corylus avellana, Pinus sylvestris, Prunus padus, Salix spp., forest litter, soil and dead basidiomata.

The similar dominance order of preferable wood substrates was revealed for other protected areas in the Orel Region such as the I. $\mathrm{S}$. Turgenev state museum-reserve "SpasskoeLutovinovo" (Volobuev, 2011). Most of 105 aphyllophoroid fungi species were developed on aspen (30 species), hazel (28 species) and birch (22 species). Ten species were associated with oak, bird cherry tree and willow. Forest ecosystems on both compared territories are situated close to the northern border of the nemoral zone within the Orel Region, and these forests are presented by restoring plant communities where Populus tremula plays a role of deciduous-inhabiting fungi successor. On the other side, the trophic structure of 148 aphyllophoroid fungi species known from forests of the South-East of the Orel region (Volobuev, 2013) differs significantly. The predominance of oak wood associated fungal species (60 species) has been shown along with 42 species registered on birch and 21 species - on aspen. The change of substrate preferences of aphyllophoroid fungi can be explained by the wood maturity of different trees and the development level or recovery stage of the forest community.

As a result of present study five rare species and species occasional for Europe (Bernicchia, 2005; Bernicchia \& Gorjón, 2010), Antrodiella fragrans, Hericium cirrhatum, Perenniporia narymica, Punctularia strigosozonata, and Skeletocutis odora, were recorded in the Naryshkinskij Natural Park. Antrodiella fragrans is restrictedly distributed in broad-leaved forests of Central and Eastern Europe, including European Russia to the Urals, where it has a distinct ecological preference to hardwood genera, especially Corylus and Prunus (Ryvarden \& Gilbertson, 1993; Spirin \& Malysheva, 2006). In the Orel Region Antrodiella fragrans also grows on Betula, Populus, Quercus, and once it was found on Larix (Volobuev, 2012). Perenniporia narymica is a rare eastern and southern species in Europe, known from Asia and Northern America, but was not found in the northern part of the conifer zone (Gilbertson \& Ryvarden, 1987; Ryvarden \& Gilbertson, 1994). Being described by A. Pilát (1936) from Siberia on rotten wood of Betula verrucosa, this species is adapted to several dead hardwoods, and also registered on fallen trunks of Acer platanoides and Betula verrucosa in the Orel Region (Volobuev \& Bondartseva, 2012; Volobuev, 2013). According to the recent study based on combined ITS +nLSU sequences of specimens from different geographical regions, Perenniporia narymica belongs to a well-supported monophyletic clade and has to be placed among a new genus Yuchengia (Zhao et al., 2013). Punctularia strigosozonata is an ex- 
clusively rare species in Northern Europe (Kotiranta et al., 2009) and rare in Eastern Europe (Parmasto, 1960; Bondartseva et al., 2000), but common in more eastern and southern regions (Yurchenko, 2002). In spite of the sufficiently wide range of occupied deciduous trees, including Acer, Alnus, Betula, Populus, Quercus, Salix, Sorbus (Bondartseva et al., 2000), aspen wood is the main substrate for this fungus. Thus the presence of aspen forests as well as old-growth ones with aspen participation can be assumed as the limiting factor of the Punctularia strigosozonata distribution in Europe. Skeletocutis odora is a very rare species in Western Europe and rare from Scandinavia to Siberia and North America, being included in the Red Lists of several European countries (European..., 2001). This species usually grows on conifers (Picea, Pinus) or on aspen in boreal regions (Ek et al., 2002; Niemelä, 2005; Kotiranta et al., 2009). Before the present investigation Skeletocutis odora was revealed in the Orel Region only from the "Orlovskoe Poles'e" National Park on Populus tremula (Kotkova et al., 2011). The species is characterized by naturally sporadic occurrence and low population density. Nevertheless this species prefers wet forests undisturbed by human activity, where there is an optimal balance of moisture and temperature.

\section{ANNOTATED LIST OF SPECIES}

Antrodia HYalina Spirin, Miettinen \& Kotir. - on fallen logs of Populus tremula, aspen-birch forest (LE 292181).

AnTrodia Malicola (Berk. \& M.A. Curtis) Donk - on fallen logs of Populus tremula, aspenbirch forest (LE 292185, OHHI 0876).

ANTRODIELla FRAGRANS (A. David \& Tortič) A. David $\&$ Tortič - on fallen logs of Populus tremula and Betula pendula, birch-aspen and pinebirch forests (LE 292178, OHHI 1139).

Antrodiella Pallescens (Pilát) Niemelä \& Miettinen - on fallen brances and logs of Betula pendula, birch-aspen forest (LE 292200).

ARTOMYCES PYXIDATUs (Pers.) Jülich - on stumps and fallen logs of Populus tremula, grassy aspen forest (LE 292206).

Athelia ePiPhylla Pers. - on fallen logs and branches of Populus tremula, aspen-birch forest (LE 292169, OHHI 0868).

AURISCALPIUM VUlgare Gray - on old cones of Pinus sylvestris, pine-birch forest (LE 295276).
Basidioradulum crustosum (Pers.) Zmitr., Malysheva \& Spirin - on fallen and standing logs and branches of Quercus robur, oak-birch with Pteridium aquilinum forest (LE 292167, OHHI 0867).

BJERKANDERA ADUSTA (Willd.) P. Karst. - on fallen stumps and logs of Populus tremula, birchaspen forest (LE 292153, OHHI 0860).

CANTHARELLUS CIBARIUS Fr. - on soil, mycorrhizaforming species, pine-birch forest (LE 292160).

Ceriporia excelsa S. Lundell ex Parmasto on fallen branches and debris of Populus tremula, aspen-birch forest (LE 292171).

Ceriporia PURPUREa (Fr.) Donk - on fallen logs of Populus tremula, grassy aspen forest (LE 292205).

Clavulina cinerea (Bull.) J. Schröt. - on litter, pine-birch forest (LE 292161).

Clavulina coralloides (L.) J. Schröt. - on litter and wood debris, oak-aspen-birch forest (LE 292164).

Cylindrobasidium laeve (Pers.) Chamuris - on standing trees of Populus tremula, aspenbirch forest (LE 292183).

DAEDAleOPSis CONFRAGOSA (Bolton) J. Schröt. - on dry standing trees and dead branches of Salix spp., birch-aspen forest.

DAEDALEOPSIS TRICOLOR (Bull.) Bondartsev \& Singer - on fallen logs of Betula pendula, birch-aspen forest.

Datronia Mollis (Sommerf.) Donk - on fallen trunks, branches and logs of Populus tremula, birch-aspen forest (LE 292187).

Fomes fomentarius (L.) Fr. - on standing trees, stumps, fallen logs, and timber of Betula pendula and Populus tremula, all forest types.

FOMITIPORIA PUNCTATA (Pilát) Murrill - on standing and fallen logs and branches of Salix spp. and Prunus padus, birch-aspen forest.

Fomitopsis PINICOLA (Sw.) P. Karst. - on standing and fallen logs, stumps of Betula pendula, birch-aspen forest.

Ganoderma applanatum (Pers.) Pat. - on stumps, fallen trunks and logs of Populus tremula and other deciduoud trees, birch-aspen and oak-birch forest (LE 292155).

Gloeoporus Dichrous (Fr.) Bres. - on fallen trunks and logs of Quercus robur, oakaspen-birch forest (LE 292168).

HaPALOPILUS Nidulans (Fr.) P. Karst. - on fallen branches and logs of Betula pendula and 
Quercus robur, birch-aspen and oak-birch with Pteridium aquilinum forests (LE 292191, OHHI 0880, OHHI 0881).

* Hericium CirRhatum (Pers.) Nikol. - on fallen trunk and logs of Populus tremula, aspenoak-birch and birch-aspen forests (LE 292162, OHHI 0865).

* Hydnum Repandum L. - on soil, mycorrhizaforming species, cereal-grassy birch forest (LE 292210).

Hymenochaete Rubiginosa (Dicks.) Lév. - on stumps, fallen trunks and logs of Quercus robur, oak-birch forest (LE 292211).

HyMENOCHAETE TABACiNa (Sowerby) Lév. - on fallen branches and logs of Prunus padus, cerealgrassy birch forest (LE 292225).

HyPHODERMA SETIGERUM (Fr.) Donk - on stumps, fallen and standing trunks, logs and branches of Betula pendula, Populus tremula and Quercus robur, birch-aspen, oak-aspenbirch and aspen-birch forests (LE 292217, OHHI 0896, OHHI 0897).

HyPHODONTIA BARBA-JOVIS (Bull.) J. Erikss. - on standing tree and dry branches of Betula pendula and dead basidiomata of Fomes fomentarius, birch-aspen forest (LE 292156, OHHI 0862).

HYPHODONTIA ERASTII Saaren. \& Kotir. - on fallen logs and branches of Betula pendula, aspenbirch forest (LE 292170).

HYPHODONTIA NESPORI (Bres.) J. Erikss. \& Hjortstam - on fallen and standing trunks and logs of Quercus robur, oak-aspen-birch and oak-birch forests (LE 292190, OHHI 0879).

HyPhODONTIA RADUla (Pers.) Langer \& Vesterh. - on fallen trunks of Populus tremula, dry standing logs and dead branches of Salix spp., birch-aspen and cereal-grassy birch forests (LE 292209, OHHI 0891, OHHI 0892).

Hyphodontia sambuci (Pers.) J. Erikss. - on fallen logs and branches of Populus tremula, aspen-birch forest (LE 292213).

Hyphodontia SPATHulata (Schrad.) Parmasto - on fallen logs of Populus tremula, aspen-birch forest (LE 292218, OHHI 0898).

Hyphodontia subalutacea (P. Karst.) J. Erikss. - on fallen logs and branches of Quercus robur, oak-birch forest (LE 292222).

HyPOCHNICIUM PUNCTULATUM (Cooke) J. Erikss. - on fallen trunk and stump of Betula pendula and basidiome of Ganoderma applanatum, birch-aspen and oak-birch forests (LE 292204, OHHI 0890).

InONOTUS OBLIQUUS (Ach. ex Pers.) Pilát - on fallen and standing dry trunks of Betula pendula, birch-aspen forest (LE 292195, OHHI 0883).

Junghuhnia Autumnale Spirin, Zmitr. \& Malysheva - on fallen trunks and logs of Populus tremula, birch-aspen forest (LE 292214).

JunghUHNIA NITIDA (Pers.) Ryvarden - on fallen branches of Betula pendula, pine-birch forest (LE 292192).

LAXiteXTUm BICOLOR (Pers.) Lentz - on fallen trunks of Populus tremula, oak-aspen-birch forest (LE 292157).

MACROTYPHULA FISTULOSA (Holmsk.) R.H. Petersen - on fallen branches of Betula pendula, pinebirch forest (LE 292174).

MACROTYPHULA JUnCEA (Alb. \& Schwein.) Berthier - on fallen branches of Betula pendula, birch-aspen with Pteridium aquilinum forest (LE 292182).

Merulius TREMELlosus Schrad. - on stumps and fallen logs of Populus tremula, oak-aspenbirch forest (LE 295270).

Mytatoderma mutatum (Peck) C.E. Gómes - on stumps, fallen trunks, logs and branches of Quercus robur, oak-birch with Pteridium aquilinum forest (LE 292188).

*OdONTICIUM SEPTOCYSTIDIA (Burt) Zmitr. \& Spirin - on fallen logs of Quercus robur, oak-birch forest (LE 292216).

OXYPORUS CORTICOLA (Fr.) Ryvarden - on fallen logs of Betula pendula, aspen-birch forest (LE 292166).

OXYPORUS LATEMARginatus (Durieu \& Mont.) Donk - on fallen trunk and logs of Betula pendula, birch-aspen forest (LE 292184).

PENIOPHORELLA PRAETERMISSA (P. Karst.) K.H. Larss. - on fallen trunks and logs of Quercus robur and Betula pendula, birch-aspen and aspenbirch forests (LE 292199, OHHI 0889).

Peniophorella PUBERA (Fr.) P. Karst. - on standing trees and fallen logs of Betula pendula, birch-aspen forest (LE 292202).

Perenniporia NARYMica (Pilát) Pouzar - on fallen trunks of Populus tremula, birch-aspen with Pteridium aquilinum forest (LE 292189).

Phanerochaete Velutina (DC.) P. Karst. - on fallen trunks, logs and branches of Betula pendula, Populus tremula and Quercus robur, birchaspen and oak-birch forests (LE 295275, OHHI 0903, OHHI 0904). 
Phellinus Igniarius (L.) Quél. - on dry logs and dead branches of Salix spp., birch-aspen forest.

Phellinus Populicola Niemelä - on living trees of Populus tremula, grassy aspen forest.

Phellinus tremulae (Bondartsev) Bondartsev $\&$ P.N. Borisov - on living and dry trunks of Populus tremula, birch-aspen forest (LE 295271).

Phlebia RAdiata Fr. - on fallen logs of Populus tremula, birch-aspen with Pteridium aquilinum forest (LE 292207).

Phlebia Rufa (Pers.) M.P. Christ. - on fallen trunks, logs and branches of Betula pendula and Populus tremula, birch-aspen and aspen-birch forests (LE 292212, OHHI 0893, OHHI 0894, OHHI 0895).

POLYPORUS ALVEOLARIS (DC.) Bondartsev \& Singer - on fallen logs of deciduous tree, birchaspen forest.

* Polyporus tubaeformis (P. Karst.) Ryvarden $\&$ Gilb. - on fallen logs of Populus tremula, birch-aspen forest (LE 295273).

POLYPORUS VARIUS (Pers.) Fr. - on fallen branches and logs of Populus tremula and some other deciduous trees, grassy aspen and aspenbirch forests (LE 295274).

Porotheleum FIMBRiatum (Pers.) Fr. - on fallen logs of Populus tremula, grassy aspen forest (LE 292172).

Postia ALNi Niemelä \& Vampola - on fallen logs and trunks of Betula pendula and Populus tremula, aspen-birch forest (LE 292154, OHHI 0861).

Postia TEPHROLEUCA (Fr.) Jülich - on fallen trunks, logs and dry branches of Betula pendula and Populus tremula, aspen-birch and birchaspen with Pteridium aquilinum forests (LE 295269, OHHI 0900, OHHI 0901).

Punctularia strigosozonata (Schwein.) P.H.B. Talbot - on dry branches of Populus tremula, birch-aspen with Pteridium aquilinum forest (LE 292219).

RADUlOMYCES MOLARIS (Chaillet ex Fr.) M.P. Christ. - on fallen trunks, logs and branches of Betula pendula and Quercus robur, pine-birch, oak-birch and oak-birch-aspen forests (LE 292186, OHHI 0877, OHHI 0878).

Schizophyllum commune Fr. - on fallen logs of Populus tremula, aspen-birch forest.

SCHIZOPORA FLAVIPORA (Berk. \& M.A. Curtis ex Cooke) Ryvarden - on standing and fallen trunks, logs and branches of Betula pendula Populus tremula, Quercus robur, Salix spp. and dead basidiomata of Fomes fomentarius, birch-aspen, oak-birch and cereal-grassy birch forests (LE 292175, LE 292176, LE 292177, OHHI 0869, OHHI 0871, OHHI 0875).

Schizopora PARAdOXa (Schrad.) Donk - on fallen trunks and logs of Quercus robur, birchaspen and oak-birch forests (LE 292201, OHHI 0886, OHHI 0887).

SistotREMA BRINKMANNII (Bres.) J. Erikss. - on fallen logs and debris of Populus tremula, birch-aspen forest (LE 292158).

Sistotrema OBLONGisPoRUM M.P. Christ. \& Hauerslev - on fallen logs of Populus tremula, aspen-birch forest (LE 292196).

SistotREMASTRUM NIVEOCREMEUM (Höhn. \& Litsch.) J. Erikss. - on fallen logs and debris of Betula pendula, aspen-birch forest (LE 292194).

Skeletocutis NiveA (Jungh.) Jean Keller - on fallen logs and branches of Betula pendula, birch-aspen and pine-birch forests (LE 292193, OHHI 0882).

SkeleTOCUTIS ODORA (Sacc.) Ginns - on standing dry trunk of Populus tremula, aspen-birch forest (LE 298598).

Steccherinum fimbriatum (Pers.) J. Erikss. - on fallen trunk of Quercus robur, birch-aspen forest (LE 292173).

STECCHERINUM OCHRACEUM (Pers.) Gray - on fallen trunks, logs and branches of Corylus avellana and Populus tremula, birch-aspen, oak-birch and oak-aspen-birch forests (LE 292198, OHHI 0884, OHHI 0885).

Stereum Gausapatum (Fr.) Fr. - on standing dry trunks and logs of Quercus robur, oak-pinebirch forest (LE 292179).

Stereum hirsutum (Willd.) Pers. - on fallen branches of Betula pendula, birch-aspen forest (LE 292180).

Stereum SAnguinolentum (Alb. \& Schwein.) Fr. on fallen logs of Pinus sylvestris, pine-birch forest (LE 292215).

Stereum subtomentosum Pouzar - on fallen trunks, logs and branches of Betula pendula, birch-aspen forest (LE 292223).

TOMENTELLA BRYOPHILA (Pers.) M.J. Larsen - on fallen trunks, logs and branches of Betula pendula, Populus tremula and Pinus sylvestris, birch-aspen with Pteridium aquilinum, aspen-birch and pine-birch forests (LE 292159, OHHI 0863 OHHI 0864). 
Tomentella Radiosa (P. Karst.) Rick - on fallen branches of Betula pendula, birch-aspen with Pteridium aquilinum forest (LE 292208).

TOMENTELLA STUPOSA (Link) Stalpers - on stumps, fallen logs and branches of Betula pendula and Quercus robur, oak-birch with Pteridium aquilinum and aspen-birch forests (LE 292220, OHHI 0899).

TRAmetes GiBBosa (Pers.) Fr. - on fallen logs and branches of Populus tremula, birch-aspen forest.

TRAMETES HIRSUTA (Wulfen) Lloyd - on fallen logs of Quercus robur, oak-birch forest.

TRAmetes ochracea (Pers.) Gilb. \& Ryvarden - on fallen logs of Populus tremula, grassy aspen forest (LE 292197).

TRAmetes suaveolens (L.) Fr. - on fallen trunks and logs of Populus tremula, birch-aspen forest (LE 292221).

TRAMETES TROGII Berk. - on stumps, fallen trunks and logs of Populus tremula, birch-aspen and aspen-birch forests (LE 295272, OHHI 0902).

TRAMETES VERSICOLOR (L.) Lloyd - on fallen logs of Populus tremula, aspen-birch forest.

TRICHAPTUM BIFORME (Fr.) Ryvarden - on fallen logs of Betula pendula, birch-aspen forest.

TubULICRINIS subulatus (Bourdot $\&$ Galzin) Donk - on fallen logs and branches of Pinus sylvestris, pine-birch forest (LE 292224).

TYPHULA PHACORRHIZA (Reichard) Fr. - on fallen leaves, litter and debris of Quercus robur and other deciduous trees, pine-birch and oakaspen-birch forest (LE 292203, OHHI 0888).

Vuilleminia COMEdens (Nees) Maire - on dry branches of Quercus robur, oak-birch forest (LE 292163).

\section{ACKNOWLEDGMENTS}

I am very grateful to my scientific adviser Prof. Margarita Bondartseva for constant encouragement. I would like to thank Michail Okun for linguistic corrections and the anonymous reviewer for valuable comments on the manuscript. The study was supported by The Ministry of education and science of Russian Federation, project 14.132.21.1328, and the Russian Foundation for Basic Research, project 12-04-31867.

\section{REFERENCES}

Bernicchia, A. 2005. Polyporaceae s. 1. Fungi Europaei, vol. 10. Ed. Candusso. 808 pp.
Bernicchia, A. \& Gorjón, S. P. 2010. Corticiaceae s. 1. Fungi Europaei, vol. 12. Ed. Candusso. 1009 pp.

Bondartseva, M. A., Lositskaya, V. M. \& Zmitrovich, I. V. 2000. Punctularia strigosozonata (Punctulariaceae) in Europe. Karstenia 40: 9-10.

Breitenbach, J. \& Kränzlin, F. 1986. Fungi of Switzerland. Vol. 2. Non-gilled fungi: Heterobasidiomycetes, Aphyllophorales, Gasteromycetes. Lucerne. $412 \mathrm{pp}$.

Ek, T., Suško, U. \& Auzinš, R. 2002. Inventory of Woodland Key Habitats (Methodology). Riga. 73 pp.

Eriksson, J., Hjortstam, K. \& Ryvarden, L. 1978. The Corticiaceae of North Europe. Vol. 5. Mycoaciella - Phanerochaete. Oslo. Pp. 887-1048.

European Council for the Conservation of Fungi (ECCF). 2001. Datasheets of threatened mushrooms of Europe, candidates for listing in Appendix I of the Convention. Strasbourg. $43 \mathrm{pp}$.

Gilbertson, R. L. \& Ryvarden, L. 1987. North American Polypores. Vol. 2. Oslo. Pp. 431-886.

Gribova, S. A., Isachenko, T. I. \& Lavrenko, E. M. 1980. Vegetation of European part of USSR (in Russian). Leningrad. $429 \mathrm{pp}$.

Hansen, L. \& Knudsen, H. (eds). 1997. Nordic macromycetes Vol. 3: Heterobasidioid, aphyllophoroid and gasteromycetoid Basidiomycetes. Copenhagen. $445 \mathrm{pp}$.

Kirk, P. M., Cannon, P. F., Minter, D. W. \& Stalpers, J. A. 2008. Ainsworth \& Bisby's dictionary of the fungi. 10th edition. Wallingford. $771 \mathrm{pp}$.

Kiseleva, L. L., Prigoryanu, O. M. \& Parakhina, E. A. 2010. Key Botanical Areas of the Orel region (in Russian, English summary). Uchenye zapiski Orlouskogo Gosudarstvennogo Universiteta. Ser. natural, technical and health sciences 2: 116-121.

Kotiranta, H., Saarenoksa, R. \& Kytövuori, I. 2009. Aphyllophoroid fungi of Finland. A check-list with ecology, distribution, and threat categories. Norrlinia 19: 1-223.

Kotkova, V. M., Bondartseva, M. A. \& Volobuev, S. V. 2011. Aphyllophoraceous fungi of the National park "Orlovskoye Poles'e" (Orel Region) (in Russian, English summary). Mikologiya i Fitopatologiya 45(1): 35-47.

Krüger, D., Petrsen R. H. \& Hughes, K. W. 2006. Molecular phylogenies and mating study data in Polyporus with special emphasis on group "Melanopus" (Basidiomycota). Mycological Progress 5(4): 185-206. http://dx.doi.org/10.1007/ s11557-006-0512-y

Niemelä, T. 2005. Polypores - lignicolous fungi (in Finnish, English summary). Norrlinia 13: 1-320.

Núñez, M. \& Ryvarden, L. 1995. Polyporus (Basidiomycotina) and related genera. Oslo. $85 \mathrm{pp}$.

Ogureeva, G. N., Kiseleva, L. L. \& Prigoryanu, O. M. 2006. Long-term dinamics of forests in the centre of the Russian plain (in Russian). Proceedings of the 2nd Regional Conference dedicated to memory of Professor Stepan Ivanovich Efremov. Orel. Pp. 170-175. 
Parmasto, E. 1960. Some rare fungi of the order Aphyllophorales (in Russian, English and Estonian summaries). Tartu Riikliku Ülikooli Toimetised 93, Botaanika-alased tööd IV: 196-208.

Pilát, A. 1936. Additamenta ad floram Sibiriae Asiaeque orientalis mycologicam. Pars tertia. Bulletin Trimestriel de la Société Mycologique de France 51(3-4): 351-426.

Ryvarden, L. \& Gilbertson R. L. 1993. European Polypores. Part 1. Oslo. Pp. 1-393.

Ryvarden, L. \& Gilbertson R. L. 1994. European Polypores. Part 2. Oslo. Pp. 394-743.

Sharapenko, A. P. (ed.). 2000. Geographical Atlas of the Orel Region (in Russian). Moscow. 48 pp.

Spirin, W. A. \& Malysheva V. F. 2006. New records of the Antrodiella species in Russia (in Russian). Novitates systematicae plantarum non vascularium 40: 189-195.

Spirin, V., Miettinen, O., Pennanen, J., Kotiranta, H. \& Niemelä, T. 2013. Antrodia hyalina, a new polypore from Russia, and A. leucaena, new to Europe. Mycological Progress 12: 53-61. http:// dx.doi.org/10.1007/s11557-012-0815-0

Volobuev, S. V. 2011. Aphyllophoraceous fungi of the I. S. Turgenev state museum-reserve "SpasskoeLutovinovo" (Orel Region) (in Russian, English summary). Mikologiya i Fitopatologiya 45(6): 489-496.
Volobuev, S. V. 2012. First data on aphyllophoroid fungi of the "Shatilovskii les" protected area (Orel Region) (in Russian, English summary). Uchenye zapiski Orlovskogo Gosudarstvennogo Universiteta, Ser. Natural, technical and health sciences 6(1): 103-107.

Volobuev, S. V. 2013. Aphyllophoraceous fungi of forest ecosystems in the South-East of the Orel Region (in Russian, English summary). Mikologiya $i$ Fitopatologiya 47(4): 209-217.

Volobuev, S. V. \& Bondartseva, M. A. 2012. Aphyllophoraceous fungi (Basidiomycota) of "Urochishche Golovkina Dubrava" protected forest area (Orel Region) (in Russian, English summary). Novitates systematicae plantarum non vascularium 46: 85-91.

Yurchenko, E. O. 2002. Non-poroid aphyllophoraceous fungi proposed to the third edition of the Red Data Book of Belarus. Mycena 2(1): 31-68.

Zhao, C.-L., Cui, B.-K. \& Steffen K. T. 2013. Yuchengia, a new polypore genus segregated from Perenniporia (Polyporales) based on morphological and molecular evidence. Nordic Journal of Botany 31: 331-338. http://dx.doi.org/10.1111/j.17561051.2012.00003.x 